Factors That Influence The Application Of Accounting Conservatism In Finance Reports (Empirical Study In Manufacturing Companies Which Are Listed In The Jakarta Stock

Exchange Period 2011-2014)

\title{
Factors That Influence The Application Of Accounting Conservatism In Finance Reports (Empirical Study In Manufacturing Companies Which Are Listed In The Jakarta Stock Exchange Period 2011-2014)
}

\author{
Rega Chairunnisya ${ }^{1^{*}}$, Afrizal ${ }^{2}$, and Wirmie Eka Putra ${ }^{3}$ \\ University of Jambi, Jambi, Indonesia
}

\begin{abstract}
This research has an aim to empirically prove the influence of a company's broad size, audit committee, growth opportunities, firm size, firm risk, capital intensity, and leverage on accounting conservatism. The research sample are the manufacturing companies listed on the Indonesia Stock Exchange (BEI) in the period of 2011-2014 which was chosen by purposive sampling and 28 companies in criteria were obtained.

This research used the multiple linear regression for data analysis. The results of the research showed that (1) broad size, audit committee, growth opportunities, firm size, firm risk, capital intensity, and leverage had a simultaneous influence to accounting conservatism, (2) broad size, firm size, and firm risk had a partial influence to accounting conservatism, (3) audit committee, growth opportunities, capital intensity, and leverage do not have partial influence to accounting conservatism.
\end{abstract}

Keywords: Accounting Conservatism, Audit Committee, Broad Size, Capital Intensity, Firm Size, Firm Risk, Growth Opportunities, Leverage

\section{INTRODUCTION}

Financial reports have to fulfill the aim, regulations and principles of accounting which are corresponding with the general applied regulations to be able to produce financial reports which are able to be accountable and beneficial to every user. One of the principles that is embraced in the financial reporting process is the conservatism principle. Conservatism is an attitude or view in facing uncertainty for taking action or deciding based on the worst outcome of the uncertainty (Soewardjono, 2010). The implication of this concept to financial reporting is that generally accounting will acknowledge soon the costs or losses which most likely will occur but are not anticipated (acknowledging first) the profit or income that will come though they are very likely to occur. The phenomenon of the presence of a case which has occurred in the Indonesia Stock Exchange as a cause of that flexibility which are such as PT. Kimia Farma and PT. Indofarma. The cases which occurred on Kimia Farma and Indofarma showed the failure in accounting conservatism, where the management party are not careful in presenting financial reports so it causes an overstate of profit on net profit. In this case the

* Corresponding author. Email address: chairunnisyarega@yahoo.com 
company is judged to have excess optimism in acknowledging profit so the profit value becomes larger than it should.

The cases that have occurred produced several thoughts which support the need of the conservatism principle in financial reports, because the parties of interest desire to neutralize the optimism attitude of company managers in reporting their business results. External parties such as creditors and investors need information that are related with the company specifically profit information in financial reports. One of the principles which is related with profit information and financial reports is accounting conservatism.

\section{Problem Formulation}

The problem formulation in this research is able to be outlined as the following:

1. Do the Board of Commissioners, Auditing Committee, Growth Opportunities, Company Size, Company Risk, Capital Intensity, and Leverage simultaneously influence To Accounting Conservatism in Manufacturing Companies which are listed in the Indonesia Stock Exchange period 20112014?

2. Do the Board of Commissioners, Auditing Committee, Growth Opportunities, Company Size, Company Risk, Capital Intensity, and Leverage partially influence To Accounting Conservatism in Manufacturing Companies which are listed in the Indonesia Stock Exchange period 2011-2014?

3. Do the Board of Commissioners, Auditing Committee, Growth Opportunities, Company Size, Company Risk, Capital Intensity, and Leverage influence To Accounting Conservatism in Manufacturing Companies which are listed in the Indonesia Stock Exchange period 2011-2014?

\section{Research Aims}

In corresponding with the stated problem formulation, the aims which are desired to be reached in this research are:

1. Provide empirical proof about the simultaneous influence of the board of commissioners, auditing committee, growth opportunities, company size, company risk, capital intensity, and leverage simultaneously influence to accounting conservatism in manufacturing companies which are listed in the Indonesia Stock Exchange period 2011-2014.

2. Provide empirical proof about the partial influence of the board of commissioners, auditing committee, growth opportunities, company size, company risk, capital intensity, and leverage simultaneously influence to accounting conservatism in manufacturing companies which are listed in the Indonesia Stock Exchange period 2011-2014.

3. Provide empirical proof of the size of the influence of the board of commissioners, auditing committee, growth opportunities, company size, company risk, capital intensity, and leverage simultaneously influence to accounting conservatism in manufacturing companies which are listed in the Indonesia Stock Exchange period 2011-2014.

\section{LITERATURE REVIEW AND HYPOTHESIS Accounting Conservatism}

Kieso and Weygandt (2002) defined that conservatism is a principle of prudence which is faced with a choice of solutions which will have small chances in producing determinations that are too high for assets and profit. Conservatism 
Factors That Influence The Application Of Accounting Conservatism In Finance Reports (Empirical Study In Manufacturing Companies Which Are Listed In The Jakarta Stock Exchange Period 2011-2014)

means if doubtful, choose the solution which will have a very small chance of producing income which is too high for assets and profit. The conservatism principle is a principle of exception or modification in the sense that the principle takes action as a limit to accounting data presentation which are relevant and reliable. (Belkaoui \& Riahi, 2004).

\section{Influence of the Board of Commissioners with Accounting Conservatism}

The research of Lara, et al. (2005) showed that companies that have a strong board requires a conservatism level which is higher than companies with a weak board. The size of the board of commissioners which is unbalanced with the size of the board of directors will cause commissioners to experience difficulties in discussing with the board of directors and supervising the corporate performance. The board of commissioners will be more desired for an application of accounting principles that are conservative for preventing deviant behavior from directors and managers.

\section{Influence of the Auditing Committee with Accounting Conservatism}

The auditing committee is tasked for helping the board of commissioners for ensuring that the financial report is presented naturally corresponding with the general applied principles of accounting, the corporate internal control structure implemented well, the implementation of internal and external audit implemented in corresponding with the applied auditing standards and further action of auditing result findings are implemented by the management. This auditing committee will ensure that the company applied the accounting principles which will produce corporate financial information that is accurate and of quality. Because of that the presence of this auditing committee will encourage the higher use of the conservatism principle in the corporate financing reporting process. This auditing committee will increase the whole quality of the corporate financing reporting process with the use of the conservatism principle.

\section{Influence of Growth Opportunities with Accounting Conservatism}

According to Mayangsari and Wilopo (2002), companies that use accounting conservatism in their financial reports, is identical with companies that grow. This is said because of the availability of a hidden reserve in those companies which are used for investment or to enlarge the company. With this growth investors and future investors will respond well because of the presence of goodwill. That goodwill is created because in companies which use accounting conservatism, the market value is larger than the ledger value. Then the market will also assess the investment implemented by the company positively, which a corporate cash flow increase is expected to occur in the future.

This hypothesis is supported by the research of Feltham and Ohlson (1995) and Penman (2001) which said that conservative accounting is a suitable concept because that concept shows growth of a company because the net assets reported are lower than the market value.

\section{Influence of Company Size with Accounting Conservatism}

Watts (2003) said that the decrease of political cost is one of the factors that increases the prosperity of management. Watts (2003) created a hypothesis that political cost will increase in line with company size. So the larger the size of a company, the larger also the political cost which has to be paid. This causes managers to have a tendency for decreasing profit in that period so the political cost is also able to be decreased or become more conservative (Sari and Adhariani, 2009). 


\section{Influence of Company Risk with Accounting Conservatism}

The benefit obtained if the company revealed the management, the risks are improving the corporate image, provide information to stakeholders in managing risks, decrease information asymmetric and increase the quality of corporate financial reports (Yudawijaya, 2011). Every decision determined by the company has different risk levels which causes the management to tend to apply the conservatism principle for anticipating problems that may appear in the future. This is a cause of the company that will tend to keep the performance and financial position to keep appearing good, so it is able to attract more investors for investing in the company.

\section{Influence of Capital Intensity with Accounting Conservatism}

Watts (2003) made a hypothesis that the more solid the capital of a company, the political costs will also be high. One of the factors that increases the prosperity of the management is the decrease of political costs. Based on the positive accounting theory, a manager will try to decrease the present political costs for maximizing the prosperity from himself.

From the explanation above it is able to be concluded that companies which have a high capital intensity ratio will tend to have a high profit and a high political cost. This will make managers to tend to choose a conservative accounting method by diverting profit from the current period to a future period for decreasing political costs.

\section{Influence of Leverage Relations with Accounting Conservatism}

The leverage ratio is a measurement of the condition of the company's ability in paying its long term liabilities. The larger the leverage ratio proportion a company has it shows that the ability of a company for paying off its long term liabilities is low. This will cause managers to tend to use an accounting procedure which increases profit in the current period, or tend to be not conservative (Sari and Adhariani, 2009).

\section{Research Hypothesis}

The hypothesis proposed in this research is as the following :

H1: The Board of Commissioners, Auditing Committee, Growth Opportunities, Company Size, Company Risk, Capital Intensity, and Leverage simultaneously influence To Accounting Conservatism

$\mathrm{H} 2$ : The Board of Commissioners has a positive influence to accounting conservatism.

H3: The Auditing Committee has a positive influence to accounting conservatism. H4: Growth Opportunities has a positive influence to accounting conservatism. H5: Company Size has a positive and significant influence to conservatism.

H6: Company Risk has a positive and significant influence to accounting conservatism.

H7: Capital Intensity has a positive and significant influence to conservatism.

H8: Leverage Ratio has a negative and significant influence to conservatism. 
Factors That Influence The Application Of Accounting Conservatism In Finance Reports (Empirical Study In Manufacturing Companies Which Are Listed In The Jakarta Stock Exchange Period 2011-2014)

\section{RESEARCH METHOD}

\section{Population and Sample}

The population in this research is all the manufacturing companies that are listed in the Indonesia Stock Exchange period 2011-2014. The research period covers year 2011 up to 2014 data. The sample obtaining technique which is used in this research is the purposive sampling method which is a sample obtaining technique with some certain criteria that has a purpose for obtaining samples which are representative and for avoiding misspecifications in the determination of research samples which then will influence to the research results. The sample selection criteria are as the following:

Table 1 Research Sample Criteria

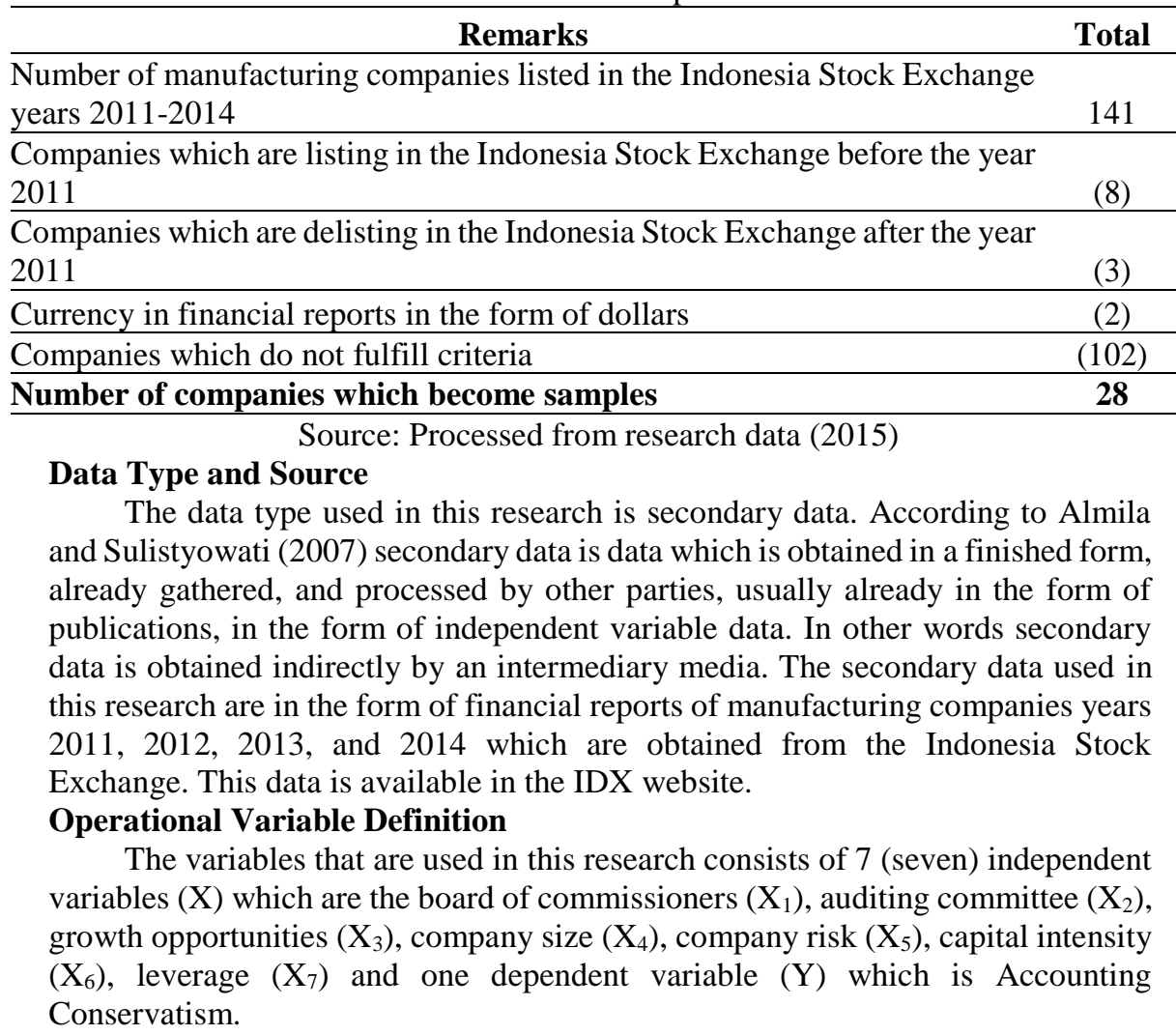

Table 2 Operational Variables

\begin{tabular}{|l|l|l|l|}
\hline \multicolumn{1}{|c|}{ Variable } & \multicolumn{1}{|c|}{ Concept } & \multicolumn{1}{c|}{ Indicator } & Scale \\
\hline $\begin{array}{l}\text { Board of } \\
\text { Commissioners } \\
\text { (BOARDSIZE) }\end{array}$ & $\begin{array}{l}\text { For } \\
\text { implementing } \\
\text { supervision and } \\
\text { provide advice to } \\
\text { the director of the } \\
\text { limited liability } \\
\text { company (PT). }\end{array}$ & $\begin{array}{l}\text { Board total board commissioners that } \\
\text { the company owns }\end{array}$ & Ratio \\
\end{tabular}




\begin{tabular}{|c|c|c|c|}
\hline Variable & Concept & Indicator & Scale \\
\hline & (Wardhani,2008) & & \\
\hline $\begin{array}{l}\text { Auditing } \\
\text { Commitee } \\
\text { (KOMAUD) }\end{array}$ & $\begin{array}{l}\text { A group of } \\
\text { persons which } \\
\text { are selected by a } \\
\text { larger group for } \\
\text { performing } \\
\text { certain tasks or } \\
\text { implement } \\
\text { certain } \\
\text { assignments. } \\
\text { (Arens.2010) }\end{array}$ & $\begin{array}{l}\qquad \begin{array}{c}\text { Total audit commitees that } \\
\text { the company owns }\end{array} \\
\text { (Wulandini. 2012) }\end{array}$ & Ratio \\
\hline \multirow{2}{*}{$\begin{array}{l}\text { Growth } \\
\text { Opportunities } \\
\text { (GROWTH) }\end{array}$} & \multirow{2}{*}{$\begin{array}{l}\text { Opportunities of } \\
\text { a company for } \\
\text { investing in } \\
\text { fields that } \\
\text { produce profit. } \\
\text { (Jogiyanto, } \\
2013 \text { ) }\end{array}$} & $\begin{array}{lll}\text { Price } & \text { earning } \\
& \text { Stock Price }\end{array}$ & \multirow[t]{2}{*}{ Ratio } \\
\hline & & $\begin{array}{l}\text { Investment Result (Earning Per Share) } \\
\text { (Jogiyanto, 2013) }\end{array}$ & \\
\hline $\begin{array}{l}\text { Company } \\
\text { Size } \\
\text { (SIZE) }\end{array}$ & $\begin{array}{l}\text { The size of the } \\
\text { company viewed } \\
\text { from the equity } \\
\text { value amount, } \\
\text { company size } \\
\text { Total corporate } \\
\text { Assets } \\
\text { =Ln Ratio } \\
\text { sales value, or } \\
\text { asset value } \\
\text { (Riyanto, 2008) }\end{array}$ & $\begin{array}{l}\text { Company size }= \\
\text { Ln Total corporate assets }\end{array}$ & Ratio \\
\hline $\begin{array}{l}\text { Company } \\
\text { Risk (RP) }\end{array}$ & $\begin{array}{l}\text { The risk that the } \\
\text { company faces to } \\
\text { sensitivity of } \\
\text { market } \\
\text { movement. } \\
\text { (KBBD }\end{array}$ & $\begin{array}{l}\text { Company Risk }=\beta \text { stock } \\
(\text { Sari and Adhariani, 2009) }\end{array}$ & Ratio \\
\hline $\begin{array}{l}\text { Capital } \\
\text { Intensity } \\
\text { (MODAL) }\end{array}$ & $\begin{array}{l}\text { The amount of } \\
\text { capital which is } \\
\text { needed for } \\
\text { producing } \\
\text { income (Waluyo } \\
\text { and } \\
\text { Kearo,2002) }\end{array}$ & $\begin{array}{l}\text { Capital Intensity }= \\
\qquad \frac{\text { Total Fixed Assets }}{\text { Total Company Sales }} \\
\text { (Cynthia Sari and Desi Adhariani, 2009) }\end{array}$ & Ratio \\
\hline $\begin{array}{l}\text { Leverage } \\
(\mathrm{LEY})\end{array}$ & $\begin{array}{l}\text { Measures the } \\
\text { amount of debt } \\
\text { that funds } \\
\text { investment in the } \\
\text { company }\end{array}$ & $\frac{\text { Total Debt }}{\text { Total Assets }}$ & Ratio \\
\hline
\end{tabular}


Factors That Influence The Application Of Accounting Conservatism In Finance Reports

(Empirical Study In Manufacturing Companies Which Are Listed In The Jakarta Stock

Exchange Period 2011-2014)

\begin{tabular}{|c|c|c|c|}
\hline Variable & Concept & Indicator & Scale \\
\hline & $\begin{array}{l}\text { (Charles } \mathrm{I}\{\text {. } \\
\text { Gibson, } \\
\text { 2012) }\end{array}$ & (Sari and Adhariani, 2009) & \\
\hline $\begin{array}{l}\text { Accounting } \\
\text { Conservatism } \\
\text { (CONACC) }\end{array}$ & $\begin{array}{l}\text { A concept which } \\
\text { acknowledges } \\
\text { costs and loss } \\
\text { faster, } \\
\text { acknowledges } \\
\text { income and } \\
\text { profit slower ( } \\
\text { Indrayati, 2010) }\end{array}$ & $\begin{array}{l}\text { Market to book ratio }= \\
\text { Closing stock Price } \mathrm{x} \\
\qquad \frac{\text { Total Circulating Stock }}{\text { Total Equity }} \\
\text { Beaver and Rvan }\{20(\mathrm{~B})\end{array}$ & Ratio \\
\hline
\end{tabular}

Source : processed from research data (2015)

\section{Data Analysis Method}

\section{Descriptive Statistics}

Descriptive statistics provide an illustration or description of data which are observed from average values, deviation standards, maximum, and minimum. The result of statistic descriptive analysis will provide data which are more concise and detailed so it contains the core of the data information.

\section{Classic Assumption Test}

A hypothesis test which uses the double regression model has to be able to fulfill the classic assumption test. This has a purpose for avoiding a biased estimation bec. ause not all data are able to apply the regression model.

\section{Normality Test}

According to Ghozali (2011) the normality test has a purpose for testing if in the regression model, the disturbing variable will have a normal distribution. Which is known that the $\mathrm{t}$ test and $\mathrm{F}$ test assumed that the residual/disturbing value follows a normal distribution. If this assumption is violated, the statistical test becomes invalid for small sample numbers.

The statistical test which is able to be implemented for testing the residual normality is with the Kalmogorov-smirnov (K-S) non parametric statistical test. The K-S test is able to be implemented by creating the hypothesis :

$\mathrm{H} 0$ : normally distributed residual data

$\mathrm{Ha}:$ residual data not normally distributed

Decision making :

$\mathrm{H} 0$ rejected: if (sig)- $\mathrm{t}<0,05$

$\mathrm{H} 0$ accepted : if ( $\mathrm{sig})-\mathrm{t}>0,05$

\section{Multicolinearity Test}

According to Ghozali (2011) the multicolinearity test has a purpose for testing if the regression model finds the presence of correlations between independent variables. A good regression model should not have correlations between independent variables. If the independent variables correlate with each other these variables are not orthogonal. Orthogonal variables are independent variables which the correlation values between fellow independent variables are the same with zero. For observing the presence or absence of multicolinearity in the regression model it is able to be observed from (1) the tolerance value and its 
opposite (2) variance inflation factor (VIF). The mean of showing the presence of multicolinearity is the tolerance value.

$<0.10$ or the same with the value of VIF $>10$.

\section{Heteroscedascity test}

According to Ghozali (2011), the heteroscedascity test has a purpose for testing if in the regression model occurs a dissimilarity of variance from one observation to other observations. If the variance of the residual of one observations to other observations is fixed it is named Homoscedascity and if it is different it is named heteroscedascity. A good regression model is the homoscedascity or does not occur heteroscedascity.

\section{Autocorrelation Test}

According to Ghozali (2011) the purpose of the autocorrelation test is for knowing if in the linear regression model has correlations between the disturbing mistake of the $t$ period with the disturbing mistakes in period $t-1$. If there occurs a correlation, there is an autocorrelation problem. Autocorrelation appears because the consecutive observation all the time is related with each other. This problem appears because the residual (disturbing mistake) is not independent from one observation to other observations.

\section{Hypothesis Test}

\section{Double Regression Linear Analysis}

The double regression linear analysis is used for testing the influence of two or more independent variables to dependent variables. The double regression linear analysis in this research is used for testing the influence of the board of commissioners auditing committee, growth opportunities, company size, company risk, capital intensity, and leverage to one dependent variable which is Accounting conservatism of manufacturing companies period 2011-2014. The regression model which is developed for testing the hypotheses which are formulated in this research is :

CONACC $_{i}=\beta_{0}+\beta_{1}$ BROADSIZE $_{i}+\beta_{2} \mathrm{KOMAUD}_{i}+\beta_{3} \mathrm{GROWTH}_{i}+\beta_{4} \mathrm{SIZE}_{i}+$ $\boldsymbol{\beta}_{5} \boldsymbol{R P} \boldsymbol{P}_{i}$

$$
+\beta_{6} M_{O D A L}+\beta_{7} L E V_{i}+\varepsilon_{i}
$$

\section{Individual Parameter Significance Test (T Statistic Test)}

The $t$ statistic test basically shows how far the influence of an independent variable in explaining the dependent variable partially (Ghozali, 2011).

Another alternative for observing the influence partially is by observing the significance level, if the significance level which is formed is below 5\% there is a significant influence of the independent variable partially to the dependent variable. Conversely if the significance formed is above 5\% there is no significant influence of the independent variable partially to the dependent variable (Wibowo, 2012).

\section{Simultaneous Significance Test (F Statistic Test)}

The $\mathrm{F}$ test is implemented for testing simultaneously between independent variables to the dependent variable. The F statistic test basically shows if all have influence simultaneously to the dependent variable (Ghozali, 2014).

\section{Determination Coefficient Test $\left(\mathbf{R}^{2}\right)$}

The determination coefficient $\left(\mathrm{R}^{2}\right)$ measures how far the ability of the model in explaining the dependent variable. The determination coefficient value is between zero and one. A small $\mathrm{R}^{2}$ value shows that the ability of the independent variable in explaining variable variation is very limited. A value which is close to 
Factors That Influence The Application Of Accounting Conservatism In Finance Reports (Empirical Study In Manufacturing Companies Which Are Listed In The Jakarta Stock Exchange Period 2011-2014)

one means that independent variables provide almost all information needed for predicting dependent variables. The use of the determination coefficient has a basic weakness which is the presence of bias to the number of independent variables which are inputted in the model. For avoiding the bias, the adjusted $\mathrm{R}^{2}$ value is used, where the adjusted $\mathrm{R}^{2}$ value is able to increase or decrease if there is an addition of one independent variable (Ghozali, 2014).

\section{RESULTS AND DISCUSSION}

\section{Test Results}

In this research the counting will use the programs Microsoft Office Excel 2007 and IBM SPSS Statistic for windows release 22.0. Before analyzing data the research variables have to be counted first with applied equations using the excel program. After those variables are known, the data analysis is able to be implemented using the IBM SPSS Statistic for windows release 22.0.

Table 3 Test Results

Coefficients $^{\mathrm{a}}$

\begin{tabular}{|c|c|c|c|c|c|}
\hline \multirow[t]{2}{*}{ Model } & \multicolumn{2}{|c|}{$\begin{array}{l}\text { Unstandardized } \\
\text { Coefficients }\end{array}$} & \multirow{2}{*}{$\begin{array}{c}\text { Standardized } \\
\text { Coefficients } \\
\text { Beta } \\
\end{array}$} & \multirow[t]{2}{*}{$\mathbf{T}$} & \multirow[t]{2}{*}{ Siq. } \\
\hline & $\mathrm{B}$ & Std. Error & & & \\
\hline (Constant) & 6.999 & .502 & & 13.947 & .000 \\
\hline Lag2_Xl & .326 & .102 & .336 & 3.207 & .002 \\
\hline Lag2_X2 & .266 & .223 & .103 & 1.194 & .235 \\
\hline Lag2_X3 & -.003 & .002 & -.127 & -1.605 & .111 \\
\hline Lag2-X4 & -.887 & .138 & -.684 & -6.451 & .000 \\
\hline Lag2_X5 & .586 & .139 & .345 & 4.213 & .000 \\
\hline La2_X6 & -.125 & .080 & -.134 & -1.549 & .124 \\
\hline Lag2_X7 & .263 & .342 & .062 & .769 & .444 \\
\hline \multicolumn{6}{|c|}{ Source : SPSS 22 output results } \\
\hline
\end{tabular}

1. Based on the double regression linear analysis result with the regression model for testing the influence of the board of commissioners variable to accounting conservatism a statistical value of 3.207 is produced with a significance level of $0.002(<0.05)$. This test accepts the first hypothesis $(\mathrm{H} 2)$ which said that the board of commissioners has a positive influence to accounting conservatism. Therefore the board of commissioners has a positive and significant influence to accounting conservatism, which means the board of commissioners is one of the factors that determine the level of conservatism in financial reporting of a company which is a part of the internal side of the company in providing information that is transparent, accurate, and not misleading for the investor. This is corresponding with the research of Lara et al (2005) which said that companies which have a strong board as the internal side of the company applies a higher conservatism level than companies with weak boards. Results of this research support research results implemented by Wayan (2015) and Dwinika (2012). 
2. Based on the double regression linear analysis result with the regression model for testing the influence of the auditing committee variable to accounting conservatism an $r$ statistic value of 1.194 is produced with a significance level of 2.35 (> 0.05). This test does not accept the first hypothesis (H3) which said that the auditing committee has a positive influence to accounting conservatism. The test of this hypothesis shows that the auditing committee does not significantly influence accounting conservatism. This means that the presence of the auditing committee which is already obliged and almost all companies already have it becomes something that is obligated and needed. This occurrence is suspected as a cause of in determining the auditing committee, companies do not pay attention to the meeting frequency of the auditing committee and the accounting competence aspect from each individual which entered the auditing committee composition which is able to be seen that in some of the sample companies it was found that the meetings of the auditing committee have a low frequency and in the competence aspect which the auditing committee members have, there are some individuals with backgrounds other than accounting so the supervision to the company accounting is deficient and the financial reports produced tend to be not conservative. Results of this research support research results implemented by Wayan (2015), Dwinka (2012) and Dinny (2013).

3. Based on the double regression linear analysis result with the regression model for testing the influence of the growth opportunities (GROWTH) variable to accounting conservatism a statistical value of -1.605 is produced with a significance level of 0.111 ( $>0.05$ ). This test does not accept the first hypothesis (H4) which said that the growth opportunities has a positive influence to accounting conservatism. This shows that growth opportunities has a negative insignificant influence to accounting conservatism. This occurrence might be because not all managers apply the conservatism principle by minimalizing profit for fulfilling the needs of investment funds which companies need in their growth where the funds mostly come from external sources. Results of this research support research results of Indah (2014) and Deslatu (2009).

4. Based on the double regression linear analysis result with the regression model for testing the influence of the company size (SIZE) variable to accounting conservatism a statistical value of -6.451 is produced with a significance level of $0.000(<0.05)$. This test accepts the first hypothesis (H5) which said that the company size has a positive influence to accounting conservatism.

Large companies will have a pessimistic attitude in financial report presentation and tend to be more careful in their accounting enforcement. A company with a large size is very vulnerable to political corr, so companies that have a large size tend to present a financial report that tends to be conservative. The tighter competition and a low supply strength added with the consumer attitude that is more and more critical and preferential is able to give an impact to the company. So it causes companies to have a more conservative attitude in their financial reporting to still be in the competition. Companies of course desire the continuance of a life cycle that keeps moving, the economic situation which is constantly developing is able to make companies to be more conservative in their financial report presentation. 
Factors That Influence The Application Of Accounting Conservatism In Finance Reports (Empirical Study In Manufacturing Companies Which Are Listed In The Jakarta Stock

Exchange Period 2011-2014)

Results of this research supports the research of Alrnila (2005), Sari (2009) and Wayan (2015).

5. Based on the double regression linear analysis result with the regression model for testing the influence of the company risk (RP) variable to accounting conservatism an $r$ statistic value of 4.213 is produced with a significance level of $0.000(<0.05)$. This test accepts the first hypothesis (H6) which said that the company risk has a positive influence to accounting conservatism.

Company Risk has a positive and significant influence to the application of Accounting Conservatism. Company risk reflects the influence from market fluctuation and the impact to the company. A Company Risk which tends to be high, causes companies to more choose the method of recording which decreases profit and faster to acknowledge the loss suffered, so companies will tend to be more conservative. When the company risk which the company faces is not categorized as high risk, companies will tend to decrease the conservatism level from the company in implementing accounting recording. Risks that are faced by the company becomes an important factor which is considered by the company because the cause of a high risk is able to cripple the activities of the company. The cripple of the activities of the company is able to become a threat of the life continuity of the respective company. So companies will tend to be careful in presenting all aspects of their finance. Results of this research are supported by the research of Agustina (2015).

6. Based on the double regression linear analysis result with the regression model for testing the influence of the capital intensity (MODAL) variable to accounting conservatism an $\mathrm{r}$ statistic value of -1.549 is produced with a significance level of 0.124 (> 0.05). This test accepts the first hypothesis (H7) which said that the capital intensity has a positive influence to accounting conservatism. Capital intensity has a negative and insignificant influence to the application of Accounting Conservatism. This is caused because manufacturing companies in the 2011-2014 period are capital intensive companies so companies tend to not be careful in their accounting recording. Companies that are capital intensive certainly will not be very influenced to sales value change because in the implementation of the activities, the contribution from the company capital is larger than the sales. Yet this occurrence also depends on the field applied by the company, if it is influenced by the economic and political situation which is applied in Indonesia, because the economic and political situation is able to provide an impact the company although the company is capital intensive. The presence of an influence of the economic and political situation of the country to the company which causes the company to will tend to be more conservative in presenting its financial report and need capital supply in supporting its operational activities. If the financial condition presented by the company is not suitable with the expectations of investors, investors will soon pull out their capital from the company, which in the end is able to cause a lack of capital for operating the business. Results of this research are supported by the research of Sari (2009) and Agustina (2015).

7. Based on the double regression linear analysis result with the regression model for testing the influence of the leverage (LEY) variable to accounting conservatism an $r$ statistic value of 0.769 is produced with a significance level of 0.444 (> 0.05). This test accepts the first hypothesis (H8) which said that 
the leverage has an insignificant influence to accounting conservatism. This is because debt is not the only factor which is able to influence political cost. This can also mean that in certain situations managers apply conservatism for certain things. And it is also able to be caused because many debtors already understand the principle of accounting conservatism, so a high amount of debt is not always connected with a bad company. Results of this research are supported by the research of Agus (2015).

\section{CONCLUSION}

Based on test results and analysis implemented in part 4, the conclusion is as the following:

1. The Board of Commissioners, Auditing Committee, Growth Opportunities, Company Size, Company Risk, Capital Intensity, and Leverage simultaneously influence to accounting conservatism.

2. The Board of commissioners, company size, and, company risk influence partially to accounting conservatism while the auditing committee, growth opportunities, capital intensity, and leverage do not influence partially to accounting conservatism.

3. The Board of Commissioners, Auditing Committee, Growth Opportunities, Company Size, Company Risk, Capital Intensity, and Leverage simultaneously influence to accounting conservatism which is as large as $35.2 \%$ while the rest $64.8 \%$ are able to be explained by other variables outside of this research.

\section{Suggestions}

Based on the conclusion above the writer is able to provide suggestions as the following:

1. For assessing conservatism a company should consider the factors of the board of commissioners, auditing committee, growth opportunities, company size, company risk, capital intensity, and leverage which are proven to provide influence to accounting conservatism.

2. For future researchers which will implement the same research can consider the following factors:

a. Add other variables outside this research for strengthening research about accounting conservatism such as financial distress, litigation risk and others.

b. Lengthen the observation period so it will be able to reflect the company's condition in the long term.

c. Widen the sample selection with other industry types so there is additional opportunity for providing a maximum illustration of research results.

\section{References}

Agustina, R., \& Stephen. (2015). Analisa Faktor-Faktor yang Mempengaruhi Penerapan Konservatisme Akuntansi pada Perusahaan Manufaktur yang Terdaftar di Bursa Efek Indonesia. SNA 18 North Sumatera University, Medan. 
Factors That Influence The Application Of Accounting Conservatism In Finance Reports

(Empirical Study In Manufacturing Companies Which Are Listed In The Jakarta Stock

Exchange Period 2011-2014)

Ahmed, A. S., \& Duellman, S. (2007). Accounting Conservatism and Board of Director Characteristics: An Ampirical Analisys. Journalof Accounting and Economics.

Aji, B. B. (2010). Pengaruh Corporate Governance Terhadap Manajemen Laba pada Perusahaan Manufaktur di Bursa Efek Indonesia. [Thesis]. Semarang: Diponegoro University.

Alfian, A. (2013). Analisis Faktor-Faktor Yang Berpengaruh Terhadap Pemilihan Konservatisme Akuntansi (Studi Pada Perusahaan Manufaktur Yang Terdaftar Di BEI Tahun 2009-2011). Accounting Journal, 2(3). Faculty of Economics, Diponegoro University.

Almilia, L. S., \& and Kristijadi. (2004). Analisis Rasio Keuangan untuk Memprediksi Kondisi Financial Distress Perusahaan manufaktur yang terdaftar di BEJ. Indonesia Journal of Accounting and Auditing, 7(2), December, 183-206.

Anthony, R., \& Govindarajan, V. 2005. Management Control Systems. Jakarta: Salemba Empat.

Arikunto, S. (2010). Prosedur Penelitian: Suatu Pendekatan Praktik [Edisi Revisi]. Jakarta: Rineka Cipta.

Aristiyani, D. G. Utami., Wirawati, I. G. P. (2013). Pengaruh Debt To Total Assets, Dividen Payout Ratio and Ukuran Perusahaan pada Konservatisme Akuntansi Perusahaan Manufaktur di BEI. E- Accounting Journal Udayana University, 3(3), 216-230.

Beaver, W.H., \& Ryan, S. G. (2000). Biases and lags in book value and their effects on the ability of the book-tomarket ratio to predict book return on equity. Journal of Accounting Research, 38, 127-148.

Boediono. (2005). Ekonomi Mikro. Yogyakarta: BPFE Gadjah Mada University

Brilianti, D. P. (2013). Faktor-faktor yang Mempengaruhi Penerapan Konservatisme Akuntansi Perusahaan. Accounting Analysis Journal, 2 (3).

Chariri, A., \& Ghozali, I. (2003). Teori Akuntansi. Semarang: Baand Publisher Diponegoro University.

Chariri, A., \& Ghozali, I. (2007). Teori Akuntansi. Semarang: Faculty of Economics Diponegoro University.

Deviyanti, D. A. (2012). Faktor-Faktor Yang Mempengaruhi Penerapan Konservatisme Dalam Akuntansi. [Thesis]. Semarang: Faculty of Economics Diponegoro University. 
Dewi, N. S. (2014). Pengaruh Struktur Kepemilikan Institusional, Struktur Kepemilikan Publik Debt Covenant, and Growth Opportunities Terhadap Konservatisme Akuntansi. JOM Fekon, 1(2).

Fala, D. Y. A. S. (2007). Pengaruh Konservatisme Akuntansi terhadap Penilaian Ekuitas Perusahaan Dimoderasi oleh Good Corporate Governance. Simposium Nasional Akuntansi X, IAI, 2007.

Faradillah. (2010). Pengaruh Kepemilikan Manajerial And Investment Opportunity Set (Ios) Terhadap Konservatisme Akuntansi. [Thesis]. Unpublished. Surakarta: Faculty of Economics Surakarta National University.

Fatmariani. (2013). Pengaruh Struhur Kepemilikan, Debt Covenant and Growth Opportunities terhadap Konservatisme Akuntansi pada Perusahaan Manufaktur yang Terdaftar di Bursa Efek Indonesia. Journal of Padang National University. Padang.

Ghozali, I. (2011). Aplikasi Analisis Multivariate Dengan Program SPSS. Semarang: Baand Publisher Diponegoro University.

Givoly, D., \& C, Hayn. (2000). Measuring Reporting Conservatism. http://www.ssrn.com

Harahap, S. S. (2011). Analisis Kritis atas Laporan Keuangan. Jakarta: PT Raja Grafindo Persada.

Hellman, N. (2007). Accounting Conservatism Under Ifrs. Stockholm School Of Economics.

Indonesia Bond of Accountants. (2010). Pernyataan Standar Akuntansi Keuangan. Jakarta: Salemba Empat.

Finance Accounting Journal. (2012). Jurnal Akuntansi Keuangan May 1 2012. www.Jurnalakuntansikeuangan.com

Kasmir. (2014). Dasar-Dasar Perbankan. Jakarta: PT. Raja Grafindo Persada.

Kieso, W., \& Warfield. (2008). Akuntansi Intermediate. Edisi Keduabelas. Jakarta: Erlangga.

Wulandini, D., \& Zulaikha. (2012). Pengaruh Karakteristik Dewan Komisaris, and Komite Audit Terhadap Tingkat Konservatisme Akuntansi. Diponegoro University. Journal of Accounting, 1(2). 